\title{
SIKAP AFEKTIF IBU TERHADAP IKAN LAUT NYATA MENINGKATKAN APRESIASI ANAK MENGONSUMSI IKAN LAUT
}

\author{
(Mother's Preference Towards Fish Significantly Increase Children's Appreciation \\ for Consuming Fish)
}

\author{
Waysima $^{1 *}$, Ujang Sumarwan ${ }^{2}$, Ali Khomsan ${ }^{3}$, dan Fransiska R Zakaria ${ }^{1}$ \\ 1 Departemen Ilmu dan Teknologi Pangan, Fakultas Teknologi Pertanian, Institut Pertanian Bogor, \\ Bogor 16680. \\ 2 Departemen Ilmu Keluarga dan Konsumen, Fakultas Teknologi Pertanian, Institut Pertanian Bogor, \\ Bogor 16680. \\ 3 Departemen Gizi Masyarakat, Fakultas Ekologi Manusia, Institut Pertanian Bogor, Bogor 16680. \\ Telp: 0251-8621258; Fax: 0251-8622276 \\ * Alamat korespondensi: Departemen Ilmu dan Teknologi Pangan, Fakultas Teknologi Pertanian, \\ Institut Pertanian Bogor, Bogor 16680. Email: waysima@gmail.com
}

\begin{abstract}
The relationship of mother's attitude towards specific food consumption is known to influence children's attitude and eating behavior. Fish consumption is critical towards children development, such as brain development and overall physical health. The objectives of this research were to elaborate the determinants of children's appreciation for consuming fish or attitude towards consuming fish. This cross-sectional study was conducted in two different locations in Central Java in a coastal and in a non-coastal area. There are 248 students from the fifth and sixth grades of elementary schools participating as subjects, which is the same as that of their mothers. Observations and interviews were carried out using standardized questionnaires to describe the mother and children relationship that determined children's appreciation for consuming fish by using path analysis. The results showed that location of residence namely coastal area, family collective eating pattern, mother's affective attitude towards fish and mother's higher education significantly improved children appreciation for consuming fish. However, cognitive attitude and conduct to make fish available in family menu did not contribute significantly to children appreciation for consuming fish. It can be concluded that even though mother understands the benefits of fish and makes fish available in family menu, when children unable to feel her preference towards fish, children will not appreciate to consume. Therefore, mother's preference towards fish needs special considerations, since it positively influence children's appreciation for consuming fish, which will contribute importantly to children's well-being.
\end{abstract}

Key words: Elementary students, attitude toward consuming fish, mother's affective attitude.

\section{PENDAHULUAN}

Perilaku makan pada manusia merupakan suatu proses kompleks yang dipengaruhi oleh serangkaian faktor mulai dari mekanisme biologis, genetis hingga ke faktor-faktor psikologis, sosial dan budaya (Sijtsema, 2003). Aspek psikologis pada diri manusia yang berperan pada pembentukan perilaku makan dinyatakan sebagai sikap terhadap obyek perilaku makan. Roininen (2001) dalam tesisnya mengutarakan bahwa bahan pangan yang tersedia, individu dan lingkungan sosial-ekonomi secara bersama-sama mempengaruhi pemilihan pangan (food choice). Pada anak, pola penerimaan terhadap makanan dipengaruhi oleh berbagai pengalaman sejak lahir, seperti orangtua melalui makanan yang diperbolehkan, dan kon- teks sosial dimana perilaku makan terjadi (Birch, 2002), khususnya peran ibu dalam meningkatkan asupan pangan sehat pada anak (Brown \& Ogden, 2004). Seorang ibu sering digambarkan sebagai nutritional gate-keeper ya itu seseorang di dalam rumah tangga yang berlaku sebagai pembuat keputusan membeli hingga menyiapkan makanan untuk keluarga. Selain ibu bisa juga orang-tua, nenek atau pembantu. Mulanya istilah itu diperkenalkan oleh Kurt Lewin pada tahun 1943 dan hingga sekarang di banyak buku teks nutrisi, gatekeeper digambarkan diperankan oleh perempuan (http://en.wikipedia.org/wiki). Di Indonesia sendiri, kebanyakan ibu berlaku sebagai gate-keeper bagi keluarganya, walaupun sebagian dari mereka adalah perempuan bekerja atau sekalipun di rumahnya terdapat pemban- 
tu. Oleh karenanya ibu banyak mempengaruhi pola kebiasaan makan anak. Pada suatu penelitian longitudinal (Skinner et al., 2002) pengaruh ibu dibuktikan tetap utama pada sikap anak terhadap perilaku makannya hingga anak berusia 8 tahun.

Ikan laut merupakan sumber protein, lemak, kalsium yang tinggi (Choo \& Williams, 2003). Budaya makan ikan yang tinggi telah membuktikan terjadinya peningkatan kualitas kesehatan dan kecerdasan pada anak-anak di Jepang (Khomsan, 2002), adanya hubungan nyata antara konsumsi ikan laut dengan kinerja kognitif remaja laki-laki di Swedia yang diukur tiga tahun kemudian (Al-Alberg et al., 2009), serta adanya peningkatan usia harapan hidup (Dahuri, 2003). Widyakarya Nasional Pangan dan Gizi VIII telah menetapkan patokan kecukupan konsumsi protein/kapita/hari adalah 52 gr protein dan yang berasal dari ikan untuk rata-rata penduduk Indonesia sebaiknya dapat memenuhi standar gizi yaitu 9 gr/hari. Secara nasional, rata-rata konsumsi protein asal ikan penduduk Indonesia kurang dari standar yang dipatok, yaitu 7.94 gr/hari dengan kisaran rata-rata konsumsi $1.91 \mathrm{gr} / \mathrm{hari}$ hingga 17.67 gr/hari (BPS, 2008).

Pola makan sehat telah dipromosikan selama sepuluh tahun terakhir, yang mengakibatkan ada kecenderungan masyarakat mengonsumsi makanan sehat (Gilbert, 2000). Kendala yang diperkirakan menghalangi ibu sebagai penentu menu keluarga, dalam menyediakan ikan laut adalah persepsinya tentang kesulitan membeli, menyiangi dan mengolahnya serta harga mahal. Persepsi ibu tentang duri dan bau amis sangat berperan dalam menghambat ibu mengonsumsi ikan laut (Leek et al., 2000). Demikian pula pada penelitian Suparman (2002) dan Nurdianty (2004) di beberapa tempat di pulau Jawa menunjukkan persepsi konsumen tentang bau amis menghambat konsumen mengonsumsi ikan laut.

Mempertimbangkan manfaat ikan laut yang berpengaruh positif dalam meningkatkan pembentukan kecerdasan dan kesehatan manusia, dan khususnya anak merupakan calon sumberdaya manusia yang berdayaguna di masa depan, pentinglah mempelajari fakor-faktor yang menentukan pembentukan sikap anak terhadap makan ikan laut. Penelitian sejenis di Indonesia belum banyak dilakukan dan studi ini ingin melihat khususnya peran ibu dalam meningkatkan sikap atau apresiasi anak mengonsumsi ikan laut di usia transisi dari usia anak sekolah ke usia remaja. Tujuan khusus penelitian ini adalah 1) Menganalisis karakteristik sosiodemografi keluarga di kedua wilayah dan 2) Menganalisis penentu sikap anak untuk makan ikan laut.

\section{METODE}

\section{Desain, Tempat, dan Waktu penelitian}

Desain penelitian ini adalah cross-sectional study, dilakukan di dua lokasi, wilayah pesisir di Kabupaten Jepara dan wilayah pedalaman di Kabupaten Grobogan, Propinsi Jawa Tengah. Proses pengambilan data dilakukan selama 6 bulan.

\section{Teknik Penarikan Responden}

Sampel sejumlah 248 siswa diambil dari 7385 siswa SD di kedua wilayah. Selain siswa, ibunya dilibatkan sebagai responden. Penentuan lokasi kecamatan dilakukan secara purposif, untuk mendapatkan kecamatan yang berada di daerah pesisir. Penarikan 13 sekolah dilakukan dengan mengelompokkan sekolah SD berdasarkan tingkat sosial ekonomi sekolah (dilihat dari kefavoritan sekolah). Penarikan responden dilakukan secara acak di kelas 5 dan kelas 6 yang tersedia di masing-masing sekolah yang telah ditentukan.

\section{Jenis dan Cara Pengumpulan Data}

Pengisian kuesioner dan wawancara yang dipandu merupakan alat untuk pengambilan data primer, sedang data sekunder meliputi profil dan sosio-demografi kelurahan serta kecamatan terkait dikumpulkan dari kantor pemerintah di kabupaten dan propinsi. Data karakteristik keluarga diambil dari responden ibu, meliputi pendidikan dan pekerjaan orang tua, besar keluaga, pendapatan/kapita dan pengeluaran untuk ikan laut. Data karakteristik ibu diambil dari responden ibu, meliputi persepsi ibu tentang ikan laut, ketidakpercaya annya terhadap mitos ten-tang makan ikan laut, sikap kognitif dan afektifnya terhadap ikan laut. Data karakteristik anak diambil dari responden anak, meliputi pola makan keluarga dan sikap anak terhadap makan ikan laut.

\section{Pengolahan dan Analisis Data}

Pengolahan data mencakup statistik deskriptif dari semua peubah kontinyu dan perhitungan proporsional untuk seluruh peubah kuantitatif. Analisis korelasi dan path analysis digunakan untuk menganalisis penentu sikap anak terhadap makan ikan laut. 


\section{HASIL DAN PEMBAHASAN}

\section{Sosio-Demografi Keluarga Responden}

Dari beberapa peubah karakteristik keluarga (Tabel 1) besar keluarga, usia anak, tingkat pendidikan ibu, penghasilan dan pengeluaran untuk ikan/kapita/bulan secara nyata berbeda di kedua wilayah. Besar keluarga, usia anak dan pengeluaran/kapita/bulan untuk ikan laut lebih tinggi di wilayah pesisir.

Jumlah ibu bekerja di wilayah pesisir $(58.3 \%)$ sedikit lebih banyak dari-pada di wilayah pedalaman (54.1\%). Tingkat pendidikan ibu di wilayah pedalaman secara nyata lebih tinggi. Demikian pula tingkat pendidikan ibu yang tidak bekerja (IRT), lebih tinggi di wilayah pedalaman. Berasumsi bahwa tingkat pendidikan seseorang mempengaruhi tingkat kepemilikan dan keluasan pengetahuan, maka ibu di wilayah pedalaman baik yang bekerja maupun IRT lebih berpeluang memiliki pengetahuan lebih luas. Secara signifikan penghasilan/kapita/bulan lebih tinggi di wilayah pedalaman, sebaliknya pengeluaran untuk ikan laut/kapita/bulan lebih besar di wilayah pesisir.

\section{Karakteristik Ibu}

Secara keseluruhan hasil analisis uji-t (Tabel 2) menunjukkan bahwa kondisi wilayah pesisir memungkinkan terjadinya beberapa atribut ibu yang berkaitan dengan ikan laut lebih positif dibandingkan wilayah pedalaman, yaitu dalam hal persepsi terhadap ikan laut, sikap afektif atau kesukaan terhadap ikan laut dan perilaku menyediakan ikan laut dalam menu keluarga.
Perilaku ibu menyediakan ikan laut dalam lam menu keluarga didasarkan bahwa ibu sebagai penentu menu keluarga, sehingga pengeluaran/kapita/bulan untuk pembelian ikan laut dianggap sebagai perilaku ibu menyediakan ikan dalam menu keluarga. Dengan demikian pengeluaran untuk ikan/kapita/bulan di wilayah pesisir yang secara nyata lebih tinggi menunjukkan ibu di wilayah pesisir lebih sering menyediakan ikan laut di menu keluarga.

Dua atribut ibu lainnya yaitu ketidakpercayaan terhadap mitos tentang makan ikan laut dan sikap kognitif terhadap ikan laut secara signifikan di kedua wilayah tidak berbeda. Ketidakpercayaan ibu terhadap mitos makan ikan laut yang ditanyakan melalui hal yang berkaitan dengan ibu hamil, ibu menyusui dan anak juga berkorelasi secara signifikan dan cukup kuat dengan tingkat pendidikan ibu $\left(r=0.472^{* *}\right)$ dimana tingkat pendidikan ibu di wilayah pedalaman lebih tinggi. Hasil wawancara ke beberapa responden terutama di wilayah pesisir menunjukkan bahwa generasi mereka jarang mengalami dampak buruk setelah makan ikan laut, walaupun generasi orang tua mereka masih mempercayai mitos tersebut. Pengalaman mereka mempengaruhinya untuk tidak percaya pada mitos makan ikan laut. Melihat bahwa ketidakpercayaan mereka terhadap mitos makan ikan laut yang tidak berbeda nyata menunjukkan bahwa tingkat pendidikan ibu yang lebih tinggi di wilayah pedalaman dapat diseimbangkan oleh persepsi ibu tentang ikan laut yang lebih baik di wilayah pesisir, membuat ibu di wilayah pesisir mampu meningkatkan evaluasinya tentang manfaat ikan laut. Akibatnya sikap kognitif ibu di kedua wilayah secara siginifikan tidak berbeda.

Tabel 1. Ringkasan Rataan Skor Peubah Karakteristik Sosio-Demografi Keluarga Responden di Kedua Wilayah

\begin{tabular}{lccc}
\hline \multicolumn{1}{c}{ Peubah } & \multicolumn{2}{c}{ Rataan \pm SD } & P-value \\
\cline { 2 - 4 } & Pesisir & Pedalaman & $5.15 \pm 1.39$ \\
\hline Besar keluarga (jiwa) & $5.50 \pm 1.62$ & $4.85 \pm 1.08$ & $2.02 \pm 1.41$ \\
Tingkat pendidikan ibu & $1.60 \pm 1.27$ & $2.38 \pm 1.43$ & 43.000 \\
Status kerja ibu & $41.7 \%$ IRT & $45.9 \%$ IRT & 0.000 \\
Penghasilan/kap/bulan & $301312.70 \pm 285880.17$ & $404692.99 \pm 429687.10$ & $356754.55 \pm 372904.99$ \\
Pengeluaran ikan & $24065.61 \pm 15191.25$ & $14202.35 \pm 14641.75$ & $18776.04 \pm 15664.29$ \\
\hline
\end{tabular}

Tabel 2. Ringkasan Rataan Skor Masing-masing Peubah Karakteristik Responden Ibu di kedua Wilayah

\begin{tabular}{|c|c|c|c|c|}
\hline \multirow{2}{*}{ Peubah } & \multicolumn{3}{|c|}{ Rataan \pm SD } & \multirow{2}{*}{ P-value } \\
\hline & Pesisir & Pedalaman & Total & \\
\hline Persepsi ibu & $69.10 \pm 13.61$ & $55.13 \pm 17.88$ & $61.61 \pm 17.47$ & 0.000 \\
\hline Sikap kognitif ibu & $67.54 \pm 23.32$ & $70.93 \pm 23.12$ & $69.36 \pm 23.23$ & 0.118 \\
\hline Sikap afektif ibu & $83.64 \pm 16.28$ & $72.24 \pm 17.39$ & $77.52 \pm 17.79$ & 0.000 \\
\hline Ketidakpercayaan terhadap mitos & $75.87 \pm 27.64$ & $76.64 \pm 28.66$ & $76.29 \pm 28.14$ & 0.829 \\
\hline $\begin{array}{l}\text { Perilaku ibu menyediakan ikan } \\
\text { laut dlm menu keluarga }\end{array}$ & $24065.61 \pm 15191.25$ & $14202.35 \pm 14641.75$ & $18776.04 \pm 15664.29$ & 0.000 \\
\hline
\end{tabular}




\section{Karakteristik Anak}

Kegiatan makan bersama dalam keluarga memberi pengaruh penting pada pola makan anak. Neumark-Sztainer et al. (2000) menemukan bahwa kegiatan makan bersama dalam keluarga secara positif berhubungan dengan konsumsi buah sayur biji-bijian dan makanan kaya kalsium pada anak usia remaja awal. Hasil analisis uji-t (Tabel 3) menunjukkan bahwa pola makan keluarga menurut anak, yaitu kebiasaan makan di dalam keluarga, seperti makan bersama, perhatian orang tua terhadap apa yang dimakan anak dan penyediaan masakan yang disukai keluarga menunjukkan pola yang tidak berbeda di kedua wilayah. Skor rata-rata di masing-masing wilayah menunjukkan pola makan keluarga dinilai anak kurang bagus.

Wilayah pesisir yang menyediakan ikan laut lebih banyak kuantitas dan ragamnya memberikan pengenalan responden yang lebih baik terhadap ikan laut. Selain itu pengenalan responden di wilayah pesisir terhadap ikan laut yang relatif lebih segar membawa dampak positif terhadap ke sikap anak yang lebih baik. Hasil skor rata-rata menunjukkan sikap kognitif anak di wilayah pesisir termasuk baik sedang di wilayah pedalaman termasuk cukup baik dan hasil analisis uji t (Tabel 3) menunjukkan bahwa sikap kognitif anak di wilayah pesisir secara signifikan lebih baik daripada di wilayah pedalaman. Sikap kognitif seseorang adalah keyakinan terhadap pengetahuannya tentang obyek sikap. Pengenalan, interaksi dan pengalaman anak dengan ikan laut di wilayah pesisir lebih banyak dan lebih luas. Dibandingkan dengan sikap kognitif ibu yang tidak berbeda nyata, sikap kognitif anak di kedua wilayah secara signifikan berbeda. Diduga perbedaan ini disebabkan karena perbedaan tingkat pendidikan dan pengalaman hidup mereka. Tingkat pendidikan dan pengalaman hidup ibu berkaitan dengan ikan laut lebih tinggi dan lebih banyak dibandingkan anaknya.

Secara keseluruhan, rataan skor sikap afektif anak terhadap makan ikan laut hampir sama dengan rataan skor sikap kognitifnya, yaitu termasuk cukup bagus dan hasil analisis uji t (Tabel 3) menunjukkan bahwa sikap afektif anak di wilayah pesisir secara nyata lebih baik daripada sikap afektif anak di wilayah pedalaman. Artinya tingkat kesukaan anak terhadap makan ikan laut di wilayah pesisir lebih tinggi daripada anak di wilayah pedalaman. Hasil ini sejalan dengan sikap afektif ibu yang secara nyata lebih positif di wilayah pesisir.

\section{Posisi ikan laut sebagai bahan pangan untuk lauk}

Dari 9 bahan pangan yang masing-masing responden anak dan ibu urutkan dari yang paling disukai, ternyata anak lebih banyak yang memilih daging ayam sebagai pilihan pertama daripada memilih ikan laut (Tabel 4). Sedang ibu di wilayah pesisir lebih banyak memilih ikan laut, sementara ibu di wilayah pedalaman lebih banyak memilih daging ayam. Kondisi ibu dan anak dalam memposisikan ikan laut agaknya sejalan dengan tingkat kesukaan ibu dan anak terhadap ikan laut. Rataan skor tingkat kesukaan ibu di wilayah pesisir secara nyata lebih tinggi.

Tabel 3. Ringkasan Rataan Skor Masing-masing Peubah Karakteristik Anak

\begin{tabular}{lcccc}
\hline \multicolumn{1}{c}{ Peubah } & \multicolumn{3}{c}{ Rataan \pm SD } & \multirow{2}{*}{ p-value } \\
\cline { 2 - 4 } & Pesisir & Pedalaman & Total & \\
\hline Pola makan keluarga menurut anak & $59.04 \pm 17.17$ & $55.26 \pm 18.89$ & $57.02 \pm 18.18$ & 0.208 \\
Sikap kognitif anak & $82.09 \pm 18.04$ & $63.76 \pm 25.24$ & $72.26 \pm 23.97$ & 0.000 \\
Sikap afektif anak & $77.10 \pm 18.50$ & $69.05 \pm 15.51$ & $72.78 \pm 17.40$ & 0.000 \\
\hline
\end{tabular}

Tabel 4. Ringkasan Rataan Skor Masing-masing Peubah Karakteristik Anak

\begin{tabular}{lcc}
\hline \multicolumn{1}{c}{ Kriteria } & Pesisir & Pedalaman \\
\hline Menurut ibu & & \\
Posisi ikan laut dibanding daging ayam & $61.9 \%$ ikan & $40.2 \%$ ayam \\
& $25.0 \%$ ayam & $63.0 \%$ ikan segar \\
Produk ikan yang dipilih & $70.8 \%$ ikan segar & $4.4 \%$ ikan kaleng \\
Menurut anak & $0 \%$ ikan kaleng & $15.8 \%$ ikan \\
Posisi ikan laut dibanding daging ayam & & $69.2 \%$ ayam \\
& $24.3 \%$ ikan & $32.3 \%$ ikan kaleng \\
Produk ikan yang dipilih & $56.5 \%$ ayam & $10.8 \%$ ikan pindang \\
\hline
\end{tabular}




\section{Produk Ikan Laut yang Disukai}

Produk-produk ikan laut yang tersedia di kedua wilayah adalah ikan laut segar, ikan pindang, ikan panggang (asap), ikan asin dan ikan kaleng Pilihan pertama produk ikan laut yang disukai responden ibu di kedua wilayah adalah ikan segar $(70,8 \%$ di wilayah pesisir dan $64,0 \%$ di wilayah pedalaman), namun pilihan ibu hanya menurun ke sebagian anak, yaitu $30,4 \%$ di wilayah pesisir dan $21,5 \%$ di wilayah pedalaman. Produk ikan kaleng yang paling banyak dipilih anak $(26,6 \%)$, ternyata hanya dipilih oleh $4,4 \%$ ibu dari wilayah pedalaman saja.

Faktor-faktor yang Mempengaruhi Sikap Anak terhadap Makan Ikan Laut

Model sikap anak terhadap makan ikan laut yang digunakan dalam penelitian ini mencakup beberapa faktor sosiodemografi keluarga, karakteristik ibu dan anak yang diduga mempengaruhi sikap anak. Model pembentukan sikap anak terhadap makan ikan laut memiliki nilai AGFI sebesar 0.91 berarti model ini close to fit, 91\% sikap anak terhadap makan ikan laut dapat dijelaskan oleh peubah-peubah yang ada di dalam model. Berdasarkan analisis jalur pembentukan sikap anak terhadap makan ikan laut (Gambar 1), peubah-peubah yang mempunyai kontribusi signifikan adalah wilayah pesisir, pola makan keluarga, sikap afektif, besar keluarga dan ketidakpercayaan ibu terhadap mitos. Besarnya pengaruh langsung dan tidak langsung dapat dilihat pada Tabel 5.

Secara keseluruhan wilayah pesisir memberikan kontribusi terbesar pada model sebesar $B=0.40^{*}$, yang berarti setiap kenaikan 1 skor pada peubah wilayah akan meningkatkan skor sikap anak sebesar 0.40. Kontribusi wilayah pesisir diperoleh dari pengaruh langsung sebesar $B=0.32^{*}$ dan secara tidak langsung se- besar $B=0.08^{*}$ melalui dua jalur, yaitu 1) melalui persepsi ibu, ke sikap afeksi ibu, baru ke sikap anak, dan 2) melalui sikap afeksi ibu dan langsung ke sikap anak. Besarnya pengaruh wilayah juga terlihat pada sikap anak terhadap makan ikan laut yang lebih positif di wilayah pesisir dibandingkan sikap anak di wilayah pedalaman. Hal ini menunjukkan bahwa ketersediaan ikan laut di wilayah pesisir yang relatif banyak dan segar meningkatkan keyakinan anak akan manfaat makan ikan laut dan kesukaan anak terhadap makan ikan laut.

Pola makan keluarga menurut persepsi anak berpengaruh signifikan terhadap sikap anak makan ikan laut sebesar $B=0.21^{*}$. Bila pola makan keluarga dirasakan oleh anak positif, orangtua memiliki peluang untuk mempengaruhi sikap-perilaku anak terutama dalam kegiatan yang berkaitan dengan perilaku makan. Kegiatan makan bersama orang tua menjadikan orangtua sebagai model perilaku makan yang anak tiru (Birch, 2002), mengarahkan para remaja awal untuk mengonsumsi makanan sehat (Neumark-Sztainer et al., 2000; Videon \& Manning, 2003) dan meningkatkan asupan gizi anak usia 9-14 tahun melalui makanan sehat (Gilman et al., 2000). Kegiatan makan bersama keluarga dapat berbentuk penyediaan makanan yang disukai keluarga dan interaksi orangtua dan anak yang terjadi dalam kegiatan makan (Fisher \& Birch, 1998) atau seringnya makan bersama keluarga (NeumarkSztainer et al., 2000). Skor rata-rata persepsi anak tentang pola makan keluarga di kedua wilayah termasuk kurang bagus (57). Korelasi peubah pola makan keluarga dan sikap anak terhadap makan ikan laut cukup kuat $\left(r=0.285^{*}\right)$ sehingga walaupun pola makan keluarga menurut anak kurang bagus, pola makan keluarga tetap dapat mempengaruhi sikap anak terhadap makan ikan laut.

Tabel 5. Peubah Penentu Sikap Anak terhadap Makan Ikan Laut

\begin{tabular}{lccc}
\hline \multicolumn{1}{c}{ Peubah bebas } & Efek langsung & Efek tidak langsung & Efek total \\
\hline Wilayah & $-0,32^{*}$ & $-0,08$ & $-0,40^{*}$ \\
Pendidikan ibu & 0,09 & $0,09^{*}$ & $0,19^{*}$ \\
Besar keluarga & $0,12^{*}$ & 0,00 & $0.12^{*}$ \\
Pendapatan/kap/bln & --- & 0,00 & 0,00 \\
Persepsi ibu thd ikan laut & 0,00 & 0,04 & 0,04 \\
Ketidakpercayaan mitos & $0,18^{*}$ & 0,01 & $0,19^{*}$ \\
Sikap kognitif ibu & $-0,03$ & 0,00 & $-0,03$ \\
Sikap afektif ibu & $0,19^{*}$ & 0,00 & $0,19^{*}$ \\
Perilaku ibu menyediakan & $-0,01$ & $-\cdots, 01$ \\
Pola makan keluarga & $0,21^{*}$ & --- & $-0,0,21^{*}$ \\
Usia ibu & --- & 0,00 & 0,00 \\
\hline
\end{tabular}

Keterangan: *Signifikan pada $\alpha=5 \%$ 


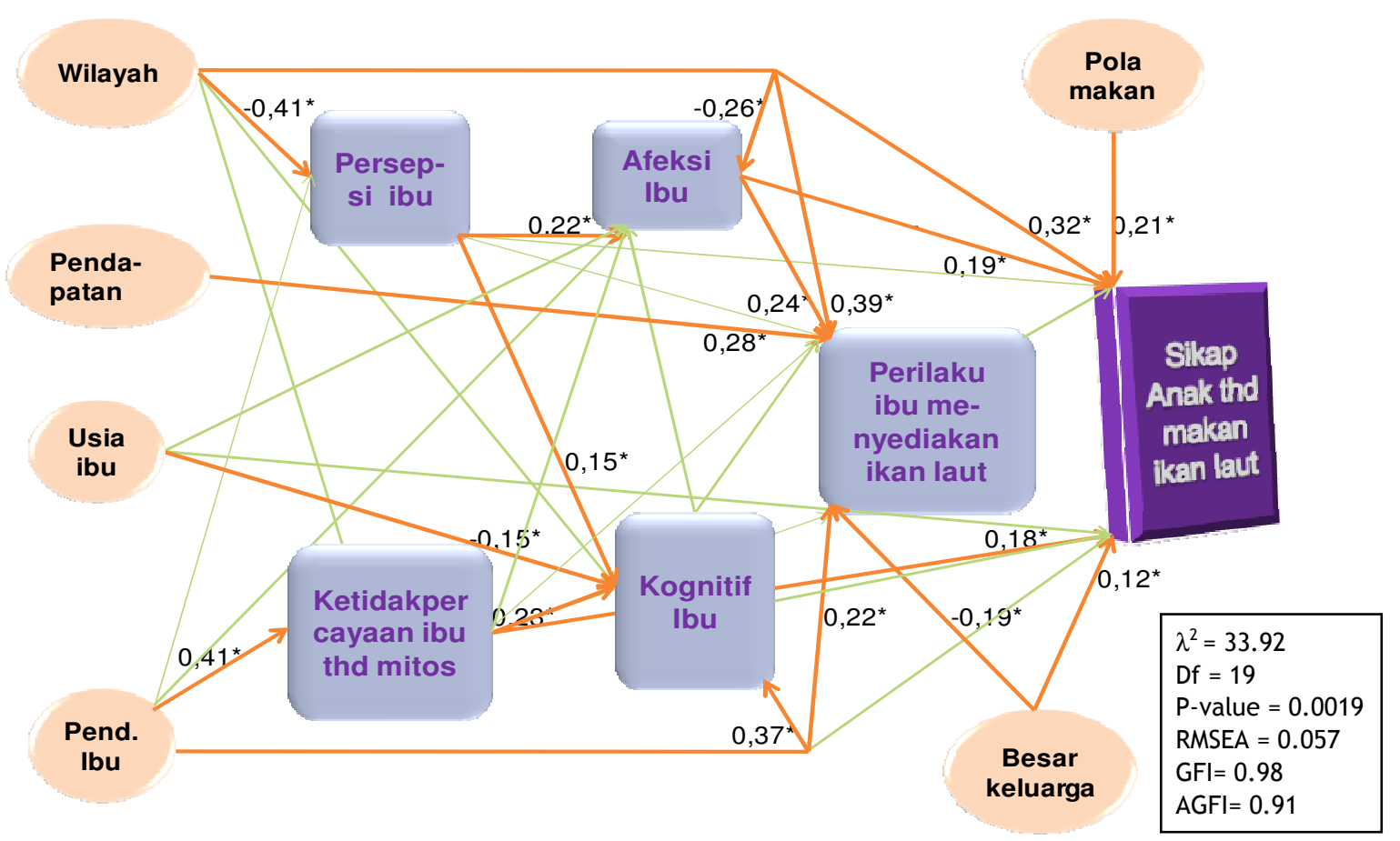

Gambar 1. Analisis jalur pembentukan sikap anak terhadap makan ikan laut.

Sikap afeksi ibu terhadap ikan laut memberi kontribusi nyata ke sikap anak terhadap makan ikan laut sebesar $0.19^{*}$. Bila dilihat sikap afeksi ibu terhadap ikan laut di kedua wilayah termasuk kategori cukup baik, dan korelasi antara sikap afektif ibu dan sikap anak terhadap makan ikan laut cukup kuat $\left(r=334^{* *}\right)$. Sikap afektif ibu selain berpengaruh langsung ke sikap anak juga berpengaruh langsung ke perilaku ibu menyediakan ikan laut dalam menu keluarga. Namun perilaku ibu menyediakan ikan laut yang dipengaruhi secara langsung oleh wilayah pesisir $(B=0.39)$, sikap afektif ibu $(B=0.24)$ dan pendidikan ibu sebesar $B=0.21$, ternyata tidak memberikan kontribusi nyata ke sikap anak. Hal ini berarti bahwa ketersediaan ikan laut dalam menu keluarga tidak membawa dampak nyata pada peningkatan sikap anak terhadap makan ikan laut.

Pendidikan ibu memberi kontribusi nyata ke sikap anak sebesar $B=0.19 *$. Secara langsung pendidikan ibu tidak mempengaruhi sikap anak, yang juga terlihat dari lemahnya korelasi pendidikan ibu dan sikap anak $(r=0.071)$. Pendidikan ibu baru memberi kontribusi nyata ke sikap anak melalui peubah ketidakpercayaan ibu pada mitos tentang makan ikan laut yang keduanya memiliki korelasi kuat $\left(r=0.406^{* *}\right)$. Bila dilihat lebih detil, terdapat korelasi cukup kuat antara ketidakpercayaan ibu terhadap mitos dengan sikap kognitif anak $\left(r=0.302^{*}\right)$. Tampaknya ketidakpercayaan ibu terhadap mi- tos mempengaruhi sikap anak terhadap makan ikan laut hanya melalui sikap kognitif anak karena korelasinya dengan sikap afekttif anak tidak nyata $(r=0.028)$.

Besar keluarga di kedua wilayah berbeda nyata $(p=0.000)$, di wilayah pesisir (6 jiwa) lebih besar daripada di wilayah pedalaman (5 jiwa). Pada model sikap anak terhadap makan ikan laut, besar keluarga memberi kontribusi nyata dan langsung sebesar $B=0.12^{*}$, artinya setiap kenaikan 1 skor pada peubah besar keluarga meningkatkan skor sikap anak sebesar 0.12 . Pola makan bersama juga merupakan salah satu bentuk hadirnya orang-orang lain pada waktu kegiatan makan. Hal serupa pada penelitian Cullen et al. tahun 2000 terhadap anakanak di usia sekolah yang menyatakan bahwa keha- diran teman-teman sebaya pada situasi makan mempengaruhi sikap dan konsumsi anak terha- dap buah sayur. Pada dasarnya kehadiran orang-orang lain pada situasi makan akan membuat sikap dan perilaku makan semakin positif.

Dari hubungan dan pengaruh peubahpeubah sosiodemografi dan karak-teristik ibu pada sikap anak terhadap makan ikan laut dapat disimpulkan bahwa wilayah pesisir sangat berperan pada sikap anak terhadap makan ikan laut. Sikap afektif ibu selain secara langsung memberi kontribusi nyata ke sikap anak, juga berlaku sebagai mediator peubah-peubah lainnya untuk mempengaruhi sikap anak. Pendidik- 
an ibu berpeluang memberi pengaruh ke sikap anak melalui ketidakpercayaan ibu terhadap mitos dan pengaruh nyata ke sikap anak itu adalah ke komponen kognitif dari sikap anak. Ketersediaan ikan laut dalam menu keluarga yang mendapat pengaruh nyata dan langsung dari peubah wilayah, pendidikan ibu dan sikap afektif ibu ternyata tidak mampu memberi kontribusi nyata ke sikap anak terhadap makan ikan laut, kecuali bila kesukaan atau sikap afektif ibu terhadap makan ikan laut bagus.

\section{KESIMPULAN}

Status sosial ekonomi keluarga responden di wilayah pedalaman secara nyata lebih tinggi daripada status sosial ekonomi keluarga responden di wilayah pesisir dilihat dari pendidikan orangtua yang lebih tinggi, jumlah anak dan besar keluarga yang lebih sedikit serta pendapatan per kapita per bulan lebih besar. Secara keseluruhan pendapatan keluarga per kapita per bulan menunjukkan bahwa sebagian besar keluarga responden termasuk golongan ekonomi menengah ke bawah.

Dalam kaitan dengan ikan laut sebagai salah satu bahan pangan untuk lauk, jalur transportasi di kedua wilayah berbeda. Jalur transportasi yang melintasi wilayah pedalaman lebih terbuka menuju ke kota-kota besar di Jawa Tengah dan Jawa Timur. Sedang jalur transportasi di wilayah pesisir lebih ter-tutup, menuju ke kota-kota kecil. Jalur transportasi terbuka memberi peluang lebih besar masuknya berbagai bahan pangan ke wilayah sehingga memungkinkan makin kecilnya pilihan masyarakat pedalaman pada bahan pangan ikan laut. Sebaliknya pada wilayah pesisir dengan jalur transportasi lebih tertutup, ragam pilihan terhadap bahan pangan menyempit, sehingga memungkinkan masyarakat lebih banyak yang memilih ikan laut sebagai bahan pangan.

Pengaruh peubah wilayah dan pendidikan ibu terhadap berbagai atribut ibu berbeda di masing-masing wilayah. Peubah wilayah berperan di wilayah pesisir sedang peubah pendidikan ibu lebih berperan di wilayah pedalaman. Persepsi ibu dan sikap afektif ibu terhadap ikan laut lebih bagus di wilayah pesisir. Ketidakpercayaan ibu terhadap makan ikan laut dan sikap kognitif ibu di kedua wilayah tidak berbeda nyata. Hal ini menunjukkan adanya peran wilayah pesisir yang dapat menyeimbangkan pengetahuan ibu tentang ikan laut sehingga sikap kognitif dan ketidakpercayaan ibu terhadap mitos di kedua wilayah tidak berbeda nyata.
Hampir seluruh peubah berkaitan dengan anak di kedua wilayah berbeda nyata dan peubah di wilayah pesisir lebih baik daripada di wilayah pedalaman, kecuali norma subyektif internal yang anak rasakan tidak berbeda nyata di kedua wilayah. Hal ini menunjukkan bahwa peran wilayah pesisir yang berarti ketersediaan ikan dalam jumlah banyak dan relatif segar di suatu wilayah sangat menentukan hal yang berkaitan dengan kegiatan anak mengonsumsi ikan laut. Ikan laut oleh anak dipilih sebagai pilihan kedua setelah daging ayam. dan di antara jenis produk ikan laut, ikan kaleng menjadi pilihan pertama bagi anak dan ikan asin menjadi pilihan terakhir.

Sikap anak terhadap makan ikan laut ditentukan oleh wilayah pesisir, pola makan keluarga, sikap afektif ibu, ketidakpercayaan ibu terhadap mitos makan ikan laut, besar keluarga dan pendidikan ibu. Tersedianya ikan laut dalam menu keluarga tidak berpengaruh nyata pada sikap anak. Selain mempengaruhi sikap anak secara nyata, sikap afeksi ibu juga mempengaruhi perilaku ibu menyediakan ikan laut dalam menu keluarga. Namun tersedianya ikan laut dalam menu keluarga tidak memberi kontribusi nyata pada sikap anak.

Sikap afektif atau kesukaan ibu terhadap ikan laut merupakan prediktor utama pada sikap anak terhadap makan ikan laut. Walaupun pendidikan dan keyakinan ibu akan manfaat ikan laut tinggi, dan ibu sudah menyediakan ikan laut dalam menu keluarga, hal ini tidak secara langsung meningkatkan apresiasi anak mengonsumsi ikan laut, hanya bila anak dapat merasakan adanya ekspresi kesukaan ibu terhadap ikan laut maka akan terjadi peningkatan apresiasi anak untuk mengonsumsi ikan laut. Selain itu sikap afektif ibu terbukti menentukan sikap anak terhadap makan ikan laut hingga anak berusia 11 tahun 5 bulan.

Selama ini upaya-upaya peningkatan konsumsi suatu pangan secara umum di rumah tangga lebih banyak dilakukan dengan anjuran peningkatan pendidikan dan pengetahuan masyarakat khususnya tentang manfaat gizi pangan tersebut. Hasil penelitian ini membuktikan bahwa upaya-upaya tersebut tidak cukup. Peningkatan pendidikan dan pengetahuan masyarakat, khususnya kaum perempuan, hendaknya disejajarkan dengan upaya penumbuhan dan peningkatan persepsi ibu tentang ikan laut dan sikap afektif atau kesukaan ibu terhadap ikan laut.

Mempertimbangkan ikan laut cukup banyak dipilih ibu sebagai bahan pangan pering- 
kat pertama, keluhan ibu tentang bau anyir dan upaya penumbuhan dan peningkatan persepsi serta kesukaan ibu terhadap ikan laut, ketersediaan ikan laut bagi konsumen sangat layak mendapatkan perhatian. Diperlukan pensosialisasian teknologi tepat guna ke masyarakat (distributor, penjual langsung dan konsumen) agar dapat mempermudah pendistribusian ikan laut sehingga memungkinkan ikan te tap dalam keadaan relatif segar sampai ke konsumen.

\section{DAFTAR PUSTAKA}

[BPS] Badan Pusat Statistik. 2008. Konsumsi Kalori dan Protein Penduduk Indonesia dan Propinsi. Buku 2. Badan Pusat Statistik Indonesia, Jakarta

Birch LL. 2002. Acquisition of food preferences and eating patterns in children. Dalam Anderson H, Bundell J, Chiva M (Eds.), Food Selection: From genes to culture. Danone Institute. http://publications. danoneinstitute.org/boutique/images_ produits/fFOODSELEC1.pdf [25 Desember 2004]

Brown R \& Ogden J. 2004 Children's eating attitudes and behaviour: a study of the modelling and control theories of parental influence. Health Education Research, 19(3), 261-271.

Choo PS, Williams MJ. 2003. Fisheries production in Asia: Its role in food security and nutrition. NAGA, Worldfish Center Quarterly, 26:2.

Dahuri R. 2003. Pidato Sambutan Menteri Kelautan dan Perikanan RI pada acara Pencanangan Gerbang Mina Bahari oleh Presiden RI di Teluk Tomini, 11 Oktober 2003. www.dkp.go.id [20 Agustus 2004].

Fisher JO \& Birch LL. 1996. Maternal restriction of young girls' food access is re- lated to intake of those foods in an unrestricted setting. FASEB J, 10, A225

Gilbert. 2000. The functional food trend: What's next and what Americans think about eggs. Journal of the American College of Nutrition, 19(5), 507S-512S.

Khomsan A. 2002. Pangan dan Gizi untuk Kesehatan. PT Rajagrafindo Persada, Jakarta.

Neumark-Sztainer D, Hannan PJ, Story M, Croll J, \& Perry C. 2000. Family meal patterns: associations with sociodemographic characteristics and improved dietary intake among adolescents.J Am Diet Assoc103, 317 -322.

Nurdianty DA. 2004. Persepsi konsumen terhadap ikan laut segar dan produk olahannya (Studi kasus di Kotamadya Jakarta Timur). Skripsi Sarjana Departemen Teknologi Pangan dan Gizi, Fakultas Teknologi Pertanian, Institut Pertanian Bogor, Bogor.

Sijtsema SJ. 2003. Your health? - Transforming health perception into jood product characteristics in consumer-oriented product design. Disertasi Doktoral Wageningen University, Netherlands.

Skinner JD, Carruth BR, Bounds W, \& Ziegler PJ. 2002. Children's Food Preferences: a longitudinal analysis. J the American Dietetic Association.

Suparman LH. 2003. Analisis Preferensi dan Faktor-faktor yang Membentuk Preferensi Konsumen tentang Produk Ikan Laut Segar. Skripsi Sarjana Departemen Teknologi Pangan dan Gizi, Fakultas Teknologi Pertanian, Institut Pertanian Bogor, Bogor.

Videon TM \& Manning CK. 2003. Influences on adolescent eating patterns: the importance of family meals. J Adolesc Health, 32, $365-373$. 